\title{
Emma Vaux: setting new standards
}

The consultant nephrologist and general physician talks to Jacqui Wise about quality improvement and medicine in the wake of the \#MeToo movement

\section{Jacqui Wise}

The BMJ

\section{Work ethic}

My father was a country GP and, although he was seemingly always on call, he loved his job. He worked incredibly hard, as did my mother, and that engendered a strong work ethic in me. By the age of 12 I was sold on the idea of medicine and I worked hard to get there.

\section{London}

I studied medicine at Charing Cross and Westminster Medical School. I loved it - the sense of community and the mix of people. You played hard and worked hard.

\section{Renal medicine}

Serendipity brought me into renal medicine. I literally opened The BMJ, saw a job on the Oxford renal rotation, and thought "go for it." I love the acute nature of the job-the emergencies. I also enjoy the long term relationships you have with patients-I particularly look after patients on haemodialysis.

\section{Specialty envy}

I enjoy my interventional work and if I had my time again I might have been tempted into the world of interventional radiology. On the research side, I have ventured from molecular genetics and working with Chinese hamster ovary cells to a particular interest in the impact dialysis has on a patient's memory and quality of life.

\section{Developing QI}

I have tried to move quality improvement on from a tick box mentality. I wanted to make doctors feel they can make a difference by focusing on small things that can have a huge impact on patients' lives or our ways of working.

\section{\#MeToo}

I have been a doctor for 28 years and have encountered all sorts of behaviour, ranging from exemplary role models to the shockingly awful. Around a year ago a senior person crossed a line and made very inappropriate remarks to me. As senior censor at the Royal College of Physicians, I thought, if I don't do anything about this, who will? So I sat down with the other

censors and we developed the RCP500 Code of Conduct (www. rcplondon.ac.uk/codeofconduct).

\section{Fun}

I try and put fun back into medicine, which I think has become a little bit lost. I have just been working, with our educationalists, on a new college publication about the modern team and how we can learn from, and with, others, not just doctors.

\section{Plans into action}

I led the Academy of Medical Royal Colleges quality improvement: training for better outcomes work which involved 35 organisations coming together culminating in published recommendations in 2016 on how to make quality improvement work in action, with patients across specialties and across different professional groups. There is real value when we recognise this isn't a silo activity.

\section{Multiple roles}

I'm also a specialty advisor with the Care Quality Commission and a case investigator and lead assessor for the National Clinical Assessment Service (now NHS Resolution). I'm not good at saying no. Most people look at me and think I'm potty with all the different jobs I do.

\section{Clinical practice}

I'm now leaning more to the education side of things, including training and continuous professional development. But it's really important to me still to be a practising clinician so I don't lose sight of what's important at the front line. 


\section{Curriculum vitae}

2003 to present: Consultant in renal and general medicine, Royal Berkshire Hospital NHS Foundation Trust

2017 to present: Senior censor and vice president (education and training), Royal College of Physicians

2010-2017: Clinical lead, Learning to make a difference, Royal College of Physicians

2013-2016: Programme director of quality improvement, Royal Berkshire Hospital NHS Foundation Trust

2013: Generation Q Fellow. The Health Foundation

2011-2013: Clinical director, acute medicine, Royal Berkshire NHS Foundation Trust

2010-2016: Associate medical director, Joint Royal Colleges of Physicians Training Board

2001: D Phil. University of Oxford

1985-1990: MBBS, Charing Cross and Westminster Medical School, University of London 